\title{
Det svenska välfärdssamhällets framväxt - tacka kvinnorna för det
}

\author{
ROLF OHLSSON
}

Det svenska välfärdssamhällets framväxt måste ses mot bakgrund av långsiktiga förändringar i ekonomin, där $i$ synnerhet den demografiska utvecklingen, kvinnornas inträde på arbetsmarknaden och den offentliga sektorn har varit viktiga. I artikeln ${ }^{1}$ identifieras de längsiktiga förändringarna genom att situationen i början av seklet jämförs med motsvarande under 1980-talet.

Det svenska välfärdssamhället och dess framväxt har i den socialvetenskapliga forskningen främst diskuterats med institutionella och politiska utgångspunkter. Det kortsiktiga perspektivet har vidare dominerat. ${ }^{2}$ Däremot har demografiska och ekonomiska angreppssätt i stor utsträckning lyst med sin frånvaro. Enligt min mening finns det emellertid långsiktiga sociala förändringsprocesser under 1900-talet, nära förknippade med den demografiska och ekonomiska utvecklingen, som i högre utsträckning än vad som hittills gjorts borde beaktas i en diskussion om or-

Rolf Ohlsson är professor i ekonomisk historia vid Lunds universitet. Hans huvudsakliga forskningsområde är ekonomisk demografi och studier av sambanden mellan demografiska, ekonomiska och sociala variabler. sakerna till det svenska välfärdssamhällets framväxt.

Det går åtminstone att identifiera tre sådana långsiktiga processer. För det första; de demografiska förändringarna, som bl.a. resulterat i att vi har fått en radikalt förändrad ålderssammmansättning $i$ befolkningen och en helt annan familjestruktur än vad som var fallet i början av seklet. Från att ha varit ett samhälle med stora familjer, många barn och få pensionärer har

1 Jag är i följande artikel medvetet sparsam med käll- och litteraturhänvisningar, eftersom artikeln främst är spekulativ till sin karaktär. Den av källor och litteratur intresserade hänvisas till en framtida (sic!) bok som är under utarbetande.

2 Detta gäller paradoxalt nog även i den socialhistoriska forskningen. 
det svenska samhället utvecklats till att bli ett samhälle med små familjer, få barn och många pensionärer. För det andra; kvinnornas inträde på arbetsmarknaden, som fått som konsekvens att ett tidigare utpräglat patriarkaliskt samhälle blivit alltmer matriarkaliskt till sin karaktär. Medan kvinnorna i början av seklet var instängda i hemmen antingen som hemmafruar eller som pigor och hembiträden, finns det nu i stort sett lika många kvinnor som män ute på den öppna arbetsmarknaden. För det tredje; framväxten av det postindustriella samhället, som inneburit en kraftig omfördelning i sysselsättningen från varuproducerande sektorer till tjänsteproducerande sektorer. Medan man i seklets början nästan uteslutande producerade jordbruksoch industrivaror, producerar man nu alltmer tjänster i form av vård, omsorg och utbildning. Jag bortser här helt från de tjänster som produceras i hemmen.

Dessa tre fundamentala sociala och ekonomiska förändringsprocesser kan ses som integrerade delar i ett komplext utvecklingsförlopp, där det inte går att identifiera några enkla orsak-verkan samband. Jag har dock valt att här ha en demografisk utgångspunkt, eftersom utvecklingen knappast kan förstås om man inte beaktar den genomgripande demografiska förändringsprocess som ägt rum och de direkta och indirekta effekter denna process haft. Ytterligare ett skäl till att betona de demografiska förändringarna är att de ofta kommit bort i diskussionerna om orsakerna till välfärdssamhällets framväxt.

Jag har vidare valt ett annorlunda angreppssätt än vad som är vedertaget inom socialvetenskaplig och socialhistorisk forsk- ning; nämligen att ta avstamp i den ekonomiska och sociala struktur som fanns i Sverige vid sekelskiftet, jämföra denna med motsvarande under 1980-talet och sedan försöka identifiera huvudlinjerna i utvecklingen. ${ }^{3}$ Den bakomliggande tanken bakom ett sådant förfarande är att en ny struktur inte kan förstås utan insikter i hur den gamla såg ut. Genom att anlägga ett långsiktigt perspektiv blir det också möjligt att fånga upp de bakomliggande orsakssammanhangen, eftersom ett alltför snävt tidsperspektiv kan resultera i att man alltför mycket betonar faktorer, som endast har ett förklaringsvärde på kort sikt. ${ }^{4}$ Dessutom framhäver man genom att anlägga ett långsiktigt perspektiv det kontinuerliga och generella i utvecklingsförloppet, och inte det diskontinuerliga och unika.

Jag har också valt att framhäva förklaringsmodeller, som är hämtade från den teoribildning som vanligtvis benämns "new home economics». Denna kontroversiella teoribildning kan karakteriseras som en mikroansats, där sociala fenomen (barnafödande, giftermål, val av utbildning m.m.) kan spåras tillbaka till rationella beteenden, inklusive altruistiska sådana, hos den enskilde individen eller hos familjen. De kan därmed analyseras med utgångspunkt i tra-

3 Motiveringen till att jag inte velat göra jämförelser med de allra senaste åren är den turbulens som rått och fortfarande råder. En jämförelse med 1990-talet skulle troligtvis ge en felaktig bild av de långa trenderna. Men om så blir fallet får framtiden utvisa.

4 Det påstående som finns i den senare delen av satsen kan ju, om man så vill, kallas en typisk "ekonomsjuka". 
ditionell neoklassisk ekonomisk teori. ${ }^{5}$ Teorin kan vidare ses som en utbudsteori, där efterfrågan ses som exogent bestämd.

Enligt min mening kompletterar denna ansats på väsentliga punkter de vedertagna förklaringar som brukar anföras i den socialhistoriska forskningen. Stundom fångar den t.o.m. upp huvudlinjerna i utvecklingen. De förklaringar som jag anför bör emellertid närmast betrakats som tentativa, eftersom hypoteser genererade från "new home economics" endast i liten utsträckning prövats empiriskt i den svenska forskningen. ${ }^{6}$

\section{Barnsamhället och pensionärssamhället}

Den mest fundamentala bakomliggande förändringen i den sociala omvandlingsprocessen under 1900-talet har otvetydigt bestått av förändringar i den demografiska strukturen. Så har de sociala omvälvningarna bland annat tagit sig uttryck i att

5 Några av standardarbetena inom området är Gary Becker, $A$ Treatise on the Family, Harvard University Press, 1993 och Alessandro Cigno, Economics of the Family, Oxford University Press, 1993.

6 Även om inte fotnoter är det rätta stället för djuplodande metoddiskussioner vill jag ändå betona att med det angreppssätt som jag valt, att jämföra situationen i början av seklet med motsvarande under 1980-talet, bör a priori den typ av teoribildning som »new home economics" teorin representerar vara rimlig att använda. Så kan den främst sägas vara en funktionsteori. Om jag istället valt att analysera förändringarna över tiden med tidsserier skulle andra typer av teorier sannolikt vara mera lämpliga. individernas livscykel och demografiska beteende ser helt annorlunda ut under 1980-talet än under tidigare perioder.

\section{Förändringar $i$ antalet barn}

I början av seklet föddes 26 barn årligen på 1000 av medelfolkmängden, medan det under 1980-talet föddes 12 barn på 1000 av medelfolkmängden. Mätt med de allmänna födelsetalen har alltså barnafödandet reducerats med mer än hälften under perioden 1900-1990.

Födelsetalens utveckling ger emellertid bara en grov och översiktlig bild av hur barnafödandet förändrats under 1900-talet, eftersom antalet årligen födda barn relaterats till den totala folkmängden. Så var ur reproduktionssynpunkt ålders- och könssammansättningen betydligt mer gynnsam vid seklets början än under 1980-talet, med betydligt fler unga kvinnor. En närmare analys visar emellertid att nedgången i barnafödandet först och främst berott på att man inom familjen av olika skäl valt att skaffa sig färre barn. Så fick en gift kvinna under slutet av 1800-talet genomsnittligt sex till sju barn efter avslutat barnafödande enligt en särskild undersökning som jag gjort över den demografiska strukturen och de demografiska förhållandena i Malmö stad. ${ }^{7}$ Egna bearbetningar av den offici-

7 Rolf Ohlsson, Den demografiska strukturen i Malmö 1825 och 1890. Stencil Lund. Jag har här bl.a. konstruerat fruktsamhetstal för olika sociala grupper, vilket den officiella statistiken inte medgör. Uppgifterna om antalet barn i texten motsvarar närmast vad som demografer brukar benämna summerade fruktsamhetstal för gifta kvinnor på kohortbasis. När det gäller fruktsamheten för gifta kvinnor är Malmö med stor sannolikhet representativ för hela landet. 
ella befolkningsstatistiken visar att detta antal hade sjunkit till i genomsnitt fem till sex barn per gift kvinna i början av sekelskiftet. ${ }^{8}$ Detta skall då jämföras med att det under 1980-talet fanns en mycket tydligt utvecklad tvåbarnsnorm för de gifta och samboende kvinnorna. ${ }^{9}$

Enligt den ovan refererade undersökningen om de demografiska förhållandena i Malmö under slutet av 1800-talet hade barnbegränsning börjat tillämpas i de högre sociala klasserna redan från omkring 1880. Detta var emellertid inte fallet $i$ arbetarklassen. En gift kvinna i arbetarklassen kom i genomsnitt att föda sju till åtta barn under sin reproduktiva period.

Det kan dessutom konstateras att det vid seklets början fanns en stor grupp kvinnor som aldrig gifte sig och som aldrig fick barn; en grupp som relativt sett var betydligt större i början av seklet än under 1980talet. Så var under åren 1901-1910 endast 40 procent av kvinnorna i åldrarna 15-44 år gifta, medan andelen gifta inklusive samboende åren under 1980-talet var 65 procent. Den viktigaste förklaringen till detta är den höga giftermảllsåldern för kvinnor 1901-10 jämfört med 1980-talet. Medan medianåldern i samband med att man flyttade samman första gången var

8 Bidrag till Sveriges officiella statistik (BiSOS): Befolkning.

9 De tal som anges i tabell 1 över summerade fruktsamhetstal skall närmast ses som summerade fruktsamhetstal för olika kohorter. Dvs. Summerade fruktsamhetstal för 1901-1910 anger hur många barn som kvinnor i åldern 40-44 år fått under sin reproduktiva period, dvs. är ett sammanfattningsmått för fertiliteten under perioden 1880-1910. några år och 20 under 1980-talet, var medianåldern vid giftermålet för kvinnor som gifte sig för första gången 26 år i början av seklet. Man finner också ett anmärkningsvärt lågt tal för andelen gifta i åldern 40-44 år i seklets början: 70 procent mot 97 procent under 1980-talet. Jag har här inkluderat änkor och skilda kvinnor i talen för de gifta eftersom jag varit intresserad av vilka kvinnor som varit särskilt och mer kontinuerligt utsatta för "risken" att bli med barn. Det låga äktenskapstalet i åldern 40-44 år visar klart att många kvinnor vid sekelskiftet, uppskattningsvis minst 30 procent av kvinnorna, aldrig gifte sig eller fick barn.

Vi kan då sammanfatta de viktigaste tendenserna i barnafödandets utveckling under 1900-talet. Den drastiska nedgång som ägt rum har först och främst berott på att familjerna av olika skäl valt att skaffa sig färre barn, från i genomsnitt fem till sex barn vid seklets början till två barn åren under 1980-talet. Med stor sannolikhet har nedgången varit ännu kraftigare i arbetarklassen och bland låginkomsttagarna. ${ }^{10}$

Ur reproduktionssynvinkel var vidare ålders- och könssammansättningen betydligt mer gynnsam vid seklets början än under 1980-talet, men samtidigt fanns det under den tidigare perioden en stor grupp kvinnor som aldrig gifte sig och som aldrig fick barn.

Den kraftiga nedgången $\mathrm{i}$ kvinnornas barnafödande kan analyseras med utgångspunkt från "new home economics»-teorin.

10 Skillnader i barnantal mellan olika sociala grupper är nuförtiden marginella. 


\section{Tabell 1}

Barnafödande i Sverige 1901-10 och 1981-90

Födelsetal, dvs. antal barn per 1000 av medelbefolkningen

Index

\begin{tabular}{rr}
$1901-10$ & $1981-90$ \\
\hline 26 & 46 \\
$400 \%$ & $65 \%$ \\
$60 \%$ & $35 \%$ \\
$70 \%$ & $97 \%$ \\
& \\
& \\
$5-6$ barn & 2 barn \\
&
\end{tabular}

Nedgången bör då ses mot bakgrund av hela den samhälleliga omvandlingen och de fundamentala strukturförändringar som ägt rum inom ekonomin sedan slutet av 1800talet. Främst kan det minskade barnafödandet ses som en anpassning till det moderna samhälle som växt fram, där den viktigaste drivkraften har utgjorts av familjernas önskan att vilja ha färre barn. Sannolikt har vid seklets början för första gången en valsituation uppstått, där familjerna kunnat välja att inte skaffa barn för att därigenom förbättra sin ekonomiska och sociala situation; en valsituation som inte förelåg i det gamla bondesamhället. Hans Alfredsson har uttryckt samma tankegång i en monolog i den något drastiska formuleringen: "Vi köper en traktor istället".

I ekonomiska termer och något förenk- lat kan nedgången i fruktsamheten ses som en konsekvens av de sjunkande intäkter och de stigande kostnader som beslutet att skaffa ytterligare ett barn skulle medföra för föräldrarna. Intäkterna av att ha barn (som riskförsäkring vid mannens eventuella bortgång, som pensionsförsäkring och som kompletterande inkomstkälla i form av barnarbete) sjönk i samband med välfärdssamhällets framväxt och beroende på tekniska och organisatoriska förändringar i näringslivet. Samtidigt steg kostnaderna för barn genom bl.a. utbildningsväsendets expansion, kvinnornas inträde på arbetsmarknaden och den tilltagande urbaniseringen. Man kan också uttrycka det så att det ägt rum ett rationellt ekonomiskt agerande från familjernas sida, som svar på förändringarna i de ekonomiska villkoren 
att föda barn till världen, och som då fått som konsekvens att barnantalet gradvis sjunkit.

Det ska också poängteras att nedgången i fruktsamheten från 1900 till 1990 inte skett jämnt och kontinuerligt utan varierat kraftigt över tiden. Följande mönster kan urskiljas: en särskilt stark nedgång under 20-talet och början av 30-talet, en stark uppgång fram till 1945, något lägre men stabila tal därefter som låg kvar på denna nivå under större delen av 50-talet, en markant uppgång fram till 1966, en mycket kraftig nedgång fram till 1983 samt en uppgång därefter. Det bör dock betonas att det under hela denna långa period varit fråga om variationer kring en nedåtgående trend. Dessa variationer förefaller i sin tur främst ha varit förknippade med förändringar på kvinnornas arbetsmarknad. När arbetsmarknadssituationen för kvinnorna varit god har barnafödandet skjutits upp, medan man tidigarelagt baranafödandet under perioder då arbetsmarknadsvillkoren varit sämre.

\section{Förändringar $i$ dödlighet}

Ytterligare en viktig faktor bakom de förändrade familjerelationerna och den förändrade familjestrukturen har varit att medellivslängden ökat radikalt. Denna ökning i återstående medellivslängd kan främst tillskrivas den stigande levnadsstandarden. De medicinska faktorerna kan ha spelat en viss roll, men sannolikt endast en marginell sådan. ${ }^{11}$

\section{1 Överhuvudtaget har man i modern forskning} ifrågasatt de medicinska faktorernas betydelse för den dödlighetsnedgång, som startade i början av 1800-talet och som fortsatt fram till
Medan den återstående medellivslängden för ett nyfött barn vid seklets början var något över 50 år, kan en pojke i det postindustriella samhället förvänta sig att bli 75 år och en flicka 80 år, om dagens dödlighetsmönster i olika åldrar skulle gälla framöver.

Det är viktigt att betona att återstående medellivslängd är ett mått som avspeglar det dödlighetsmönster som gällt ett visst år. En återstående medellivslängd på 53 år 1900 innebar att ett barn som föddes detta år genomsnittligt kom att uppnå denna ålder om han eller hon genomlevde det dödlighetsmönster som gällde just detta år. I realiteten blev de som föddes 1900 betydligt äldre.

Förändringarna i den återstående medellivslängden återspeglar i sin tur separata dödlighetsförändringar i olika åldrar, som ägt rum med varierande styrka under olika perioder. Under första hälften av seklet lyckades man genom den ökade levnadsstandarden i kombination med de medicinska framstegen bemästra infektionssjukdomarna, vilket resulterade i en kraftigt minskad dödlighet bland barn och ungdomar. Efter 1950 har det främst varit den minskade dödligheten bland de äldre som gjort att medellivslängden ökat. ${ }^{12}$

\footnotetext{
nu. I en modern amerikansk undersökning hävdas till och med att de medicinska faktorerna endast kan förklara 3,5 procent av dödlighetsnedgången i USA sedan 1900. En motsvarande svensk undersökning finns ej, men sannolikt skulle en sådan ge något motsvarande tal till resultat.

12 Det ska dock påpekas att procentuellt sett är det de yngsta som står för den kraftigaste minskningen i dödlighet även efter 1950.
} 
I första hand kan detta tillskrivas den markant förbättrade levnadsstandard som pensionärerna fått efter kriget, bland annat beroende på 1948 års pensionslag och genom ATP-reformens tillkomst. Även utvecklandet av en effektiv antibiotika kan ha spelat en viss roll i detta sammanhang. De äldre har inte i samma utsträckning som tidigare dött av en enkel förkylning.

Om vi utgår ifrån att dödligheten i olika åldrar framöver förändras på samma sätt som den gjort under de senaste 50 åren, vilket förefaller sannolikt, kan många av de barn som föds idag förvänta sig att bli närmare 100 år. De faktorer som talar för en fortsatt dödlighetsnedgång, och då särskilt i de högre åldrarna, är framstegen inom medicinsk teknik, förbättrad välfärd särskilt för de äldre, och ökad medvetenhet om hälsofrågor (kostvanor, motion, rökvanor). Däremot kan knappast dödligheten för personer i åldrarna upp till 60 år förväntas gå ner mer än mycket marginellt, i varje fall mätt i absoluta tal.

\section{Förändringar i åldersstrukturen}

Konsekvensen av den kraftiga nedgången i barnafödandet - och av den sjunkande dödligheten, men som då bara haft en marginell betydelse - är att befolkningens åldersstruktur förändrats på ett dramatiskt sätt. Denna förändrade åldersstruktur har i sin tur fått genomgripande effekter på ekonomin och på det sociala livet i största allmänhet.

Av tabell 2 framgår att andelen i s.k. produktiva eller yrkesverksamma åldrar, 15-65 år, har varit förhållandevis oförändrad över tiden: 61 procent av totalbe-

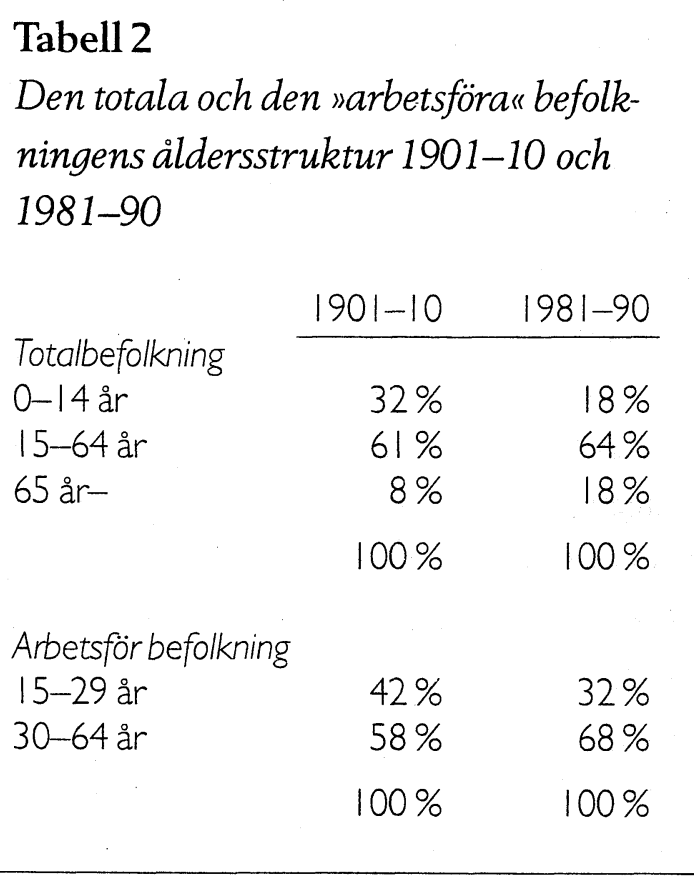

folkningen vid seklets början mot 64 procent under 1980-talet. ${ }^{13}$

Inom de yrkesverksamma åldrarna har det emellertid ägt rum stora förskjutningar i åldersstrukturen. Sedan seklets början har det skett en markant "förgubbning" och "förgumning" inom arbetsstyrkan med vittgående konsekvenser för näringslivets organisation och funktionssätt i fråga om karriärvägar, lönebildning, internutbildning, rekrytering, inställning till ny teknik, produktivitet m.m. ${ }^{14}$

13 Det ska betonas att mäta den s.k. försörjningsbördan genom att relatera antalet $i$ åldersgruppen 15-65 år till dem som är yngre och äldre är ett mycket grovt mått. Så vet vi att allt fler i åldrarna 15-25 år genomgått utbildning, samtidigt som allt fler i åldrarna 55-65 år förtidspensionerats och därför inte ingår i de »närandes" antal.

14 Rolf Ohlsson och Per Broomé, Ålderschocken, SNS, 1988. 
Den mest radikala förändringen $i$ åldersstrukturen har dock bestått i att relationen mellan antalet barn och antalet personer över 65 år förändrats. År 1900 fanns fyra gånger fler barn och ungdomar i åldrarna 0-14 år än personer i åldrarna över 65 år, medan det år 1990 fanns färre barn och ungdomar än äldre. Medan de yrkesverksammas försörjningsbörda i början av seklet nästan uteslutande avsåg barnen, måste de aktiva under 80-talet främst försörja de äldre.

Från att ha varit en mycket utpräglad barn- och ungdomssamhälle har Sverige under de senaste 90 åren utvecklats till att alltmer bli ett "medelåldersssamhälle» och ännu mer ett "pensionärssamhälle», med betydande konsekvenser för statens och kommunernas ekonomi, för bostäder, för näringslivet, för det sociala livet och för de kulturella aktiviteterna i samhället. Så kan man exempelvis konstatera att per capita kostnaderna, när det gäller de offentliga utgifterna, år 1990 var närmare tre gånger så höga för personer över 65 år som för barn och ungdomar under 20 år. ${ }^{15}$ I de offentliga utgifterna har då inkluderats statens, landstingens och kommunernas utgifter när det gäller daghem, skola, sjukvård, pensioner, äldreomsorg etc.

Den demografiska utvecklingen har också inneburit att familjestrukturen och familjerelationerna förändrats. Åren 1912-14 utgjorde enpersonhushållen ca

15 Agneta Kruse och Rolf Ohlsson: „Generational accounting - a demographic approach to public sector expenditure«. Opublicerad artikel, Lund, 1994. Dessa siffror avser år 1990. Motsvarande beräkningar för tidigare år har ännu ej gjorts.
14 procent av alla hushåll. Denna andel hade år 1985 ökat till 36 procent, bland annat beroende på den ökande skilsmässofrekvensen. De mest radikala förändringarna noteras för storfamiljhushållen. År 1912-14 utgjorde hushåll med fem personer eller fler 32 procent av alla hushållen, medan motsvarande andel år 1985 endast var några procent. ${ }^{16}$

Något förenklat och med vissa reservationer kan man påstå att dessa förändringar i hushållsstorleken avspeglar att familjerelationerna blivit vertikala, medan de under tidigare perioder var utpräglat horisontella. Ett barn har numera vanligen bara ett syskon, medan det normala förr $i$ tiden var fyra till fem. Antalet kusiner är nu begränsat till mellan fyra och sex, medan antalet kusiner förr ofta översteg tjugo. Föräldrarna är nu förtiden förhållandevis unga; man gifter sig eller blir samboende i yngre åldrar än i början av seklet och kvinnorna föder barnen tidigare och dessutom med kortare intervall. Vidare finns ofta fyra generationer levande i släkten. Detta var mycket ovanligt tidigare, beroende på den höga dödligheten, men också därför att man gifte sig så sent.

Denna förändrade familjestruktur har också inneburit att relationerna mellan generationerna har förändrats. Tvärtemot vad som allmänt förmodas har utvecklingen mot en vertikal familjestruktur

16 Jämförelse har här gjorts mellan totalbefolkningen år 1985, enligt folkräkningen, och boende i stadssamhällen, enligt den speciella bostadsräkningen 1912-1914. Om jordbruket inkluderats skulle sannolikt skillnaderna mellan seklets början och 1980-talet blivit ännu större. 
inneburit ett ökat beroende generationerna emellan. Mor- och farföräldrar, som ofta har ett yrkesliv inom industrin bakom sig, ställer ofta upp och tar hand om barnbarnen. En mycket stor del av omsorgen om de gamla utförs också av de anhöriga. Mycket talar dessutom för att det ökade antalet äldre, och särskilt då den kraftiga ökningen av antalet personer över 80 år, kommer att leda till att fler själva måste ta hand om sina åldriga släktingar. För att kompensera den minskade horisontella familjestrukturen har också sociala nätverk utanför familjen blivit allt väsentligare, och blir så sannolikt ännu mer framöver.

\section{Andra förändringar $i$ familjestrukturen}

Ytterligare tre drag i familjestrukturens utveckling under 1900-talet är särskilt värda att betona. Dessa kan i generaliserande termer sägas visa konsolideringen av kärnfamiljen under första hälften av 1900talet samt vissa uppluckringstendenser som ägt rum därefter.

För det första fanns det i början av seklet betydligt fler ogifta eller ej samboende kvinnor än vad som var fallet under 1980talet, vilket sannolikt var en konsekvens av kvarlevande demografiska tänkesätt och beteenden från det gamla bondesamhället. En intressant hypotes till varför förhållandevis få gifte sig i början av seklet kan härledas från "new home economicsu-teorin. Beroende på att kvinnornas löner var mycket låga jämfört med männens innebar giftermål en kraftig sänkning av levnadsstandarden för mannen, om vi utgår ifrån att båda parterna i äktenskapet levde på samma materiella nivå. Många män valde därför att leva ensamma. Detta var möjligt att göra i ett samhälle, där gamla traditioner och invanda tänkesätt höll på att luckras upp i samband med industrialiseringen och urbaniseringen. Under mellankrigstiden ökade sedan giftermålsfrekvensen markant, samtidigt som också kvinnornas löner ökade i förhållande till männen. Man kan påstå att den moderna kärnfamiljen därmed konsoliderades. Samtidigt sjönk också antalet utomäktenskapliga barn i rask takt.

För det andra började unga människor, särskilt efter 1965, att i allt ökad utsträckning bilda familj utan att formellt gifta sig. Orsakerna till detta är inte helt klara, men kvinnans förändrade roll på arbetsmarknaden och de stigande relativlönerna för kvinnorna jämfört med män har troligtvis haft avgörande betydelse. Även lagstiftning och en förändrad ideologi kan anföras som viktiga faktorer bakom den förändrade familjebildningsformen.

För det tredje ökade de ensamståendes andel av hushållen markant från 1960 till 1980. Detta kan främst tillskrivas den kraftiga ökningen av antalet skilsmässor. Denna tendens till försvagning av den etablerade kärnfamiljen har sannolikt utgjort en integrerad del i familjestrukturens förändring från att vara horisontell till att alltmer bli vertikal. Även i detta sammanhang kan man framföra en hypotes från "new home economicsu-teorin. Det har varit lättare att bryta upp från ett äktenskap, när parterna varit ekonomiskt jämställda, dvs. när deras löner varit ungefär lika höga, än från ett äktenskap, där löneskillnaderna varit stora och där därför också arbetsför- 
delningen mellan man och kvinna varit annorlunda.

Den drastiska skillnaden mellan situationen i början av seklet och situationen under 1980-talet framgår av följande siffror. År 1900 fanns några tusen frånskilda kvinnor $\mathrm{i}$ Sverige. År 1990 var siffran 333000 .

\section{Manssamhället och kvinnosamhället}

Parallellt och nära förknippade med förändringarna i den demografiska strukturen, har det ägt rum stora förändringar på arbetsmarknaden. Så har kvinnorna kommit att inta en alltmer framträdande plats $i$ näringslivet. Man kan påstå att näringslivet, från att ha varit utpräglat patriarkaliskt, blivit alltmer matriarkaliskt till sin karaktär.

Enligt folkräkningarna har det emellertid inte varit fråga om några revolutionerande förändringar över tiden $i$ andelen av den totala arbetsstyrkan som utgjorts av kvinnor. Av tabell 3 framgår att kvinnornas andel av de sysselsatta år 1910 var 28 procent och år 198547 procent. ${ }^{17}$

Det finns dock vissa aspekter att uppmärksamma som gör det befogat att påstå att näringslivet $\mathrm{i}$ början av seklet var mer utpräglat mansdominerat än vad den officiella statistiken visar, men att det sedan blivit alltmer dominerat av kvinnor. År 1910 arbetade 44 procent av de i statistiken angivna yrkesverksamma kvinnorna i hemmen som pigor, hembiträden, hushållerskor m.m. Denna hemarbetande yrkeskategori bestod nästan uteslutande av unga

17 Jag har här helt bortsett ifrån jordbruket.

\section{Tabell 3 \\ Kvinnor och förvärvsarbete i Sverige 1910 och 1985 \\ $1910 \quad 1985$ \\ Andelen kvinnor av det $28 \% \quad 47 \%$ \\ totala antalet sysselsatta \\ män och kvinnor \\ Andelen ogifta och ej $95 \% \quad 38 \%$ samboende kvinnor av alla sysselsatta kvinnor \\ Andelen gifta och samboende $5 \% \quad 62 \%$ kvinnor av sysselsatta kvinnor \\ Andelen kvinnor i offentlig $\quad 10 \% \quad 57 \%$ verksamhet av av alla syssel- satta kvinnor \\ Andelen pigor, hembiträden $\quad 44 \% \quad 0 \%$ m.m av alla sysselsatta kvinnor \\ Andelen kvinnor av det totala $\quad 17 \% \quad 47 \%$ antalet sysselsatta män och kvinnor, exk.l hembiträden, pigorm.fl.}

Källor.

Folkräkningen 1910 och 1985 samt arbetskraftsundersökningen 1985

Anmärkning:

Jag har helt bortsett ifrån sysselsättningen inom jordbruket

ogifta kvinnor och hade helt försvunnit fram till år 1990. Man kan något onyanserat uttrycka det som så att den kategori kvinnor som arbetade som hembiträden i seklets början antingen studerade eller arbetade som sjukvårdsbiträden eller barnskötare under 1980-talet.

Denna yrkeskategori kan, om man vill

Ohlsson - Det svenska välfärdssamhällets framväxt - tacka kvinnorna för det 
belysa kvinnornas betydelse på den öppna arbetsmarknaden, uteslutas från folkräkningens uppgifter om antalet förvärvsarbetande år 1910; då med motiveringarna att dessa kvinnor arbetade i hemmen, att de inte syntes på den öppna arbetsmarknaden och att de ur sysselsättningssynvinkel närmast kan jämföras med hemarbetande gifta kvinnor. Som resultat erhålles då att kvinnornas andel av de sysselsatta inom den öppna arbetsmarknaden ökat från 17 procent år 1910 - istället för från de officiella 28 procent - till 47 procent år 1985. Detta får betraktas som en närmast revolutionerande ökning. I absoluta tal har förändringen inneburit att under perioden 1910-1985 ökade antalet kvinnor på den öppna arbetsmarknaden, exklusive jordbruket, från 184000 till 2 miljoner, samtidigt som männens antal endast ökade från 900000 till 2 miljoner. År 1985 fanns det alltså mer än 10 gånger fler kvinnor på arbetsmarknaden än år 1910, men endast något mer än dubbelt så många män.

Den mest radikala förändringen $i$ kvinnornas sysselsättningsmönster har emellertid varit att de gifta kvinnorna i så hög grad gett sig ut på den öppna arbetsmarknaden. År 1910 utgjorde de gifta kvinnornas andel av alla förvärvsarbetande kvinnor ca 5 procent. År 1985 hade denna andel stigit till 62 procent. I absoluta tal innebär detta att det år 1910 fanns något mindre än 20000 gifta kvinnor ute på den öppna arbetsmarknaden, medan motsvarande antal år 1985 var 1,5 miljoner. I detta senare antal ingår även samboende, som inte varit formellt gifta. ${ }^{18}$

18 Enligt arbetskraftsundersökningen 1985.
Sammanfattningsvis kan vi alltså konstatera att kvinnorna under 1900-talet i allt ökad omfattning gett sig ut på den öppna arbetsmarknaden. Främst har detta gällt de gifta och samboende kvinnorna. Dessutom kan konstateras att kvinnornas inträde på den öppna arbetsmarknaden har ägt rum i betydligt större utsträckning än vad den officiella statistiken visar.

Man kan peka på flera faktorer som gjort det möjligt för i synnerhet de gifta kvinnorna att ge sig ut på den öppna arbetsmarknaden: det minskade barnafödandet, det faktum att allt fler kvinnor genomgått högre utbildning, utbyggnaden av barndaghemmen samt den tekniska utvecklingen och allt vad den inneburit i form av en förbättrad bostadsstandard, hushållsmaskiner, förädlade livsmedel etc.

De ideologiska faktorernas betydelse bör heller inte glömmas bort. Delvis kan dessa sägas avspegla de realekonomiska faktorerna, men ideologin har också spelat en självständig och förstärkande roll. Otvetydigt har det vuxit fram en ny och annorlunda syn på kvinnors arbete utanför hemmet. Denna syn har starkt avvikit från gångna tiders, då det i många fall stipulerades direkta förbud för kvinnorna att arbeta inom vissa yrken.

Kvinnornas samhälleliga roll har därmed förändrats på ett fundamentalt sätt. Flera av deras tidigare funktioner i hemmet, som exempelvis vård och utbildning av de små barnen, har i många fall förts över i samhällets och kommunens regi i form av barndaghem och fritidshem. Bakom detta har primärt legat ekonomiska och ideologiska faktorer. Man kan också påstå att de gifta kvinnorna på många sätt ersatt de äldre 
barnen och ungdomarna på arbetsmarknaden. Genom att kvinnorna gett sig ut i förvärvslivet har det blivit möjligt för många familjer att istället låta barnen gå i skola allt längre tid. Kvinnorna har på så sätt indirekt tillfredsställt samhällets och näringslivets ökade krav på utbildning och kompetens.

Det är dock uppenbart att den ökade benägenheten för kvinnorna att ge sig ut $\mathrm{i}$ förvärvslivet främst måste ses mot bakgrund av strukturellt betingade förändringar i ekonomin, som radikalt omformat familjen som ekonomisk och social organisation. Bland dessa faktorer kan man särskilt peka på de kraftigt stigande lönerna för kvinnor jämfört med män. År 1913 var den genomsnittliga timlönen för en industriarbeterska 45 procent lägre än för en manlig industriarbetare. ${ }^{19}$ Fram till år 1990 hade denna skillnad gradvis minskat till 10 procent. ${ }^{20}$ Denna minskade löneskillnad mellan män och kvinnor har emellertid inte skett jämnt och kontinuerligt utan språngartat under vissa begränsade perioder, och den har haft att göra med genomgripande strukturella förändringar i ekonomin. ${ }^{21}$

Det bör dessutom påpekas att lönerelationerna mellan män och kvinnor förändrats på motsvarande sätt i flertalet andra yrkeskategorier. I många fall har minskningen i löneskillnader varit ännu mer accentuerad än inom industrin. Som ett exempel av många kan nämnas att kvinnlig

19 Sociala Meddelanden, 1922.

20 SOS: Löner 1990.

21 Lars Svensson, Closing the Gender Gap, Lund, 1994. serveringspersonal inom hotell- och restaurangbranschen år 1915 hade 60 procent lägre lön än manlig serveringspersonal vid samma antal arbetade timmar och med i princip samma arbetsuppgifter. ${ }^{22} \AA$ r 1990 hade denna skillnad minskat till 10 procent. Sett i ett internationellt perspektiv har den löneutjämning som ägt rum mellan kvinnor och män i Sverige under 1900-talet varit helt unik.

Även här kan en hypotes från "new home economicsu-teorin anföras till de radikalt förändrade förvärvsintensiteterna och hur dessa varit relaterade till den relativa löneutvecklingen för kvinnor. Troligtvis har det tett sig alltmer lockande och lukrativt för kvinnorna att ge sig ut i förvärvslivet när deras löner ökat så radikalt som de gjort $\mathrm{i}$ förhållande till männens. De kraftigt stigande lönerna för kvinnorna jämfört med män har helt enkelt inneburit att det blivit allt dyrare för en familj att låta kvinnan stanna hemma. Samtidigt har behovet av hemarbete minskat beroende på de arbetsbesparande hjälpmedlen, de allt färre barnen och den förlängda skoltiden för barnen. Under sådana förhållanden har valet mellan hemarbete och yrkesarbete vanligtvis inte varit alltför problematiskt.

Slutligen bör det poängteras att även om kvinnorna gett sig ut på den öppna arbetsmarknaden, och därmed på många sätt revolutionerat näringslivets karaktär, har det fortfarande varit männen som förfogat över maktpositionerna. Få kvinnor har innehaft chefsposter. Flera undersökningar

22 Enligt särskild utredning om arbets- och löneförhållandena inom hotell- och restaurantbranschen år 1915 (SOS). 


\section{Tabell 4}

Näringsgrensfördelning för män och kvinnor 1910 och 1990

Industri

Handel och samfärdsel

Offentlig förvaltning

Övrigt (drängar samt

arbetare av obestämt slag)

\begin{tabular}{rr}
1910 & Män \\
\hline $60 \%$ & 1990 \\
$24 \%$ & $45 \%$ \\
$9 \%$ & $33 \%$ \\
$7 \%$ & $22 \%$ \\
& -
\end{tabular}

Industri

Handel och samfärdsel

$100 \% \quad 100 \%$

Offentlig förvaltning

Övrigt (pigor, hembiträden $\mathrm{m}$ fl)

\begin{tabular}{lr}
\multicolumn{2}{c}{ Kvinnor alternativ I } \\
\hline 1910 & 1990 \\
\hline $29 \%$ & $15 \%$ \\
$16 \%$ & $28 \%$ \\
$11 \%$ & $57 \%$ \\
$44 \%$ & -
\end{tabular}

$100 \% \quad 100 \%$

Kvinnor: alternativ 2

Industri

Handel och samfärdsel

Offentlig förvaltning

\begin{tabular}{ll}
\hline 1910 & 1990 \\
\hline $52 \%$ & $15 \%$ \\
$29 \%$ & $28 \%$ \\
$19 \%$ & $57 \%$ \\
$100 \%$ & $100 \%$
\end{tabular}

Källor: Folkräkningen 1910 och 1990 samt arbetskraftsundersökningen 1990

Anmärkning:Kvinnor: altemativ I respektive Kvinnor: alternativ 2 avser näringsgrensfördelning inklusive respektive exklusive kvinnor i husligt arbete (pigor,hembiträden m.fl.). Sysselsättningen inom jordbruket har helt bortsetts ifrån.

pekar vidare på att det inte heller skett några omvälvande förändringar när det gällt arbetsfördelningen i hemmet.

\section{Industrisamhället och omsorgssamhället}

Från att ha varit ett jordbruks- och industridominerat samhälle har Sverige under 1900-talet alltmer utvecklats till att bli ett tjänste-, vård- och omsorgssamhälle.
Omvandlingen framgår ännu tydligare om vi närmare ser på hur kvinnor och män varit sysselsatta i de olika näringarna och hur detta mönster förändrats över tiden (se tabell 4). Det framgår tydligt av tabellen att den ekonomiska omvandlingsprocessen i mångt och mycket varit relaterad till de förändringar som ägt rum i kvinnornas sysselsättning. Avindustrialiseringen har berott på att såväl antalet män som kvinnor minskat inom industrin, men den 
kraftigaste nedgången står kvinnorna för. Särskilt kraftig har nedgången varit om vi bortser ifrån kvinnor som arbetat $\mathrm{i}$ hemmen (alternativ 2 i tabellen). Vidare beror den offentliga sektorns kraftiga expansion främst på att kvinnorna tagit anställning här. Som framgår av tabell 4 var 10 pocent (19 pocent enligt alternativ 2) av de förvärsarbetande kvinnorna år 1910 sysselsatta inom den offentliga sektorn, medan motsvarande andel år 1990 var 57 procent. Denna utveckling kan också sägas ge svaren på de implicita frågor som ställdes i föregående avsnitt. Varför har kvinnornas relativlöner förändrats på det radikala sätt som de gjort? Vilka förändringar i ekonomin har legat bakom dessa förändrade relativlöner, som i förlängningen starkt bidragit till att de gifta kvinnorna i så stor utsträckning gett sig ut på arbetsmarknaden?

I denna omvandlingsprocess kan man påstå att det funnits fem grundläggande inslag i den samhällsekonomiska och sociala utvecklingen, alla direkt relaterade till välfärdssystemets framväxt och expansion: äldreomsorgens framväxt, hälso- och sjukvårdens expansion, barnomsorgens samt individ- och familjeomsorgens framväxt, och utbildningssektorns expansion. I sin tur kan dessa inslag ses som utslag av att befolkningens efterfrågan på varor och tjänster genomgått stora förändringar sedan sekelskiftet beroende på reallöneutvecklingen och de allmänna standardförbättringarna samt den genomgripande omvandlingen i näringslivets organisation och funktionssätt. Men även i detta sammanhang har de demografiska förändringarna spelat en avgörande roll. Så har det funnits direkta kopplingar mellan å ena si- dan äldreomsorgens och hälso- och sjukvårdens expansion och det ökade antalet äldre. Men även när det gäller barnomsorgen, individ- och familjeomsorgen och utbildningssektorn har det funnits indirekta samband med den demografiska utvecklingen.

\section{Äldreomsorgen}

Det kraftigt stigande antalet äldre har inneburit en ökad efterfrågan på och ett ökat behov av vård och omsorg. I tabell 5 visas andelen över 65 år respektive över 80 år av befolkningen. Medan 8 procent år 1910 var över 65 år, var motsvarande andel år 199018 procent. En mer detaljerad analys visar att det är främst i de allra äldsta åldersgrupperna som de äldres antal ökat. Av tabellen framgår att det år 1990, jämfört med år 1910, fanns 4 gånger fler i åldern 80-84 år men närmare 10 gånger fler $\mathrm{i}$ åldrarna över 90 år.

\begin{tabular}{|c|c|c|}
\hline Andel av totalbefolkningen & 1910 & 1990 \\
\hline $\begin{array}{l}65 \mathrm{a} r- \\
80 \mathrm{a} r-\end{array}$ & $\begin{array}{l}8,4 \% \\
1,3 \%\end{array}$ & $\begin{array}{r}17,8 \% \\
4,2 \%\end{array}$ \\
\hline \multicolumn{3}{|c|}{$\begin{array}{l}\text { Antalet i åldersgruppen } 1990 \text { i relation till } \\
\text { antalet } 1910\end{array}$} \\
\hline Åldersgrupp & Relation & \\
\hline $\begin{array}{l}\text { 65-69 år } \\
\text { 70-74 år } \\
75-79 a ̊ r \\
80-84 a ̊ r \\
85-89 a ̊ r \\
90 a ̊ r-\end{array}$ & $\begin{array}{l}2,6 \\
3,1 \\
3,4 \\
4,4 \\
5,3 \\
9,9\end{array}$ & \\
\hline
\end{tabular}


Man kan i och för sig argumentera för att en 70-åring år 1990 var betydligt friskare än en 70-åring vid sekelskiftet och därför inte behövt lika mycket vård. Men den ökade medellivslängden har sannolikt inneburit både fler friska år och fler år med behov av vård. Ett något drastiskt exempel belyser den helt annorlunda situationen under 1980-talet jämfört med sekelskiftet. Det tar lång tid innan man dör i Alzheimers sjukdom, men benägenheten att drabbas av denna sjukdom ökar markant med åldern. Enligt den medicinska vetenskapen drabbas ungefär 20 procent av alla över 80 år av senildemens (Alzheimer, multiinfarkt demens m.m) och 35 procent av alla över 85 år. Det innebär att år 1910 bör det i åldrarna över 80 år ha funnits ungefär 18000 personer med senildemens. År 1990 var motsvarande antal 120000 personer. Med stor sannolikhet var skillnaderna ännu större än vad dessa tal visar, bland annat beroende på att det främst varit de allra äldstas antal som ökat. Behovet av vård bestäms alltså i hög grad av hur många äldre det finns i samhället, och särskilt av hur många mycket gamla det finns.

I seklets början ansågs det primärt vara en familjeangelägenhet att ta hand om det fåtaliga antalet äldre. Någon gång kunde fattigvården tänkas träda in. En första ideologisk förändring innebar 1918 års fattigvårdslag, som markerade att det var samhällets uppgift att ta hand om de äldre. Kommunerna blev således skyldiga att inrätta ålderdomshem för äldre, friska pensionärer. Ålderdomshemmet skulle förbehållas gamla som utan egen förskyllan befunno sig i en sådan belägenhet, att de på sin ålderdom vore $\mathrm{i}$ behov av kommunens hjälp. De gamla skulle vidare beredas vård på ålderdomshemmet på sådant sätt att de så litet som möjligt saknade det egna hemmet. De skulle också om det var möjligt "slippa samföras med mindre ordentligt folku.

En andra ideologisk förändring inträffade efter 1950, då hemmaboendeideologin blev alltmer dominerande. ${ }^{23}$ En viktig orsak till denna förändring var existensen av en arbetskraftsreserv i form av hemmafruar, som kunde utnyttjas för att göra hemtjänst hos de gamla. År 1965 infördes subventioner för hemtjänst samtidigt som subventionerna för ålderdomshemmen avskaffades.

Den explosionsartade ökningen av antalet äldre, i kombination med det ökade välståndet och en potentiell arbetsstyrka i form av gifta kvinnors inträde på arbetsmarknaden, innebar en gradvis ökad efterfrågan på äldreomsorg. Denna efterfrågan accelererade särskilt efter 1970. Som konsekvens härav byggdes äldreomsorgen ut med ett rikt differentierat vårdutbud i form av social hemtjänst, färdtjänst, gruppboende, servicehus med helinackordering m.m.

Den ökade efterfrågan på äldreomsorg har inneburit ett kraftigt ökad behov av personal. Det antal som 1910 arbetade med vad som idag kallas äldreomsorg existerade knappast. År 1985 var 120000 personer verksamma inom äldreomsorgen, varav 90 procent var kvinnor. ${ }^{24}$

23 Det är troligt att det för närvarande pågår en tredje ideologisk förändring som innebär en alltmer positiv syn på institutionsvård.

24 Folk- och bostadsräkningen 1985. 


\section{Hälso- och sjukvården}

Under 1900-talet har en omfattande expansion inom hälso- och sjukvården ägt rum. Vi har förhållandevis lite kunskaper om de grundläggande drivkrafterna bakom hälsooch sjukvårdens expansion under 1900-talet. Detta kan tyckas förvånande, bl.a. av det skälet att hälso- och sjukvården tar $i$ anspråk en så stor del av de gemensamt producerade resurserna i landet. Det ökade antalet äldre kan i viss mån förklara expansionen, men bara marginellt. Så har sjukvårdsexpansionen främst berott på att sjukvårdskonsumtionen ökat per person. Åldringsexplosionen har emellertid varit betydelsefull på så sätt att de äldre blivit alltmer intensivt vårdade jämfört med yngre personer. ${ }^{25}$ Detta har bland annat berott på den tekniska utvecklingen som inneburit att man kunnat behandla sjukdomar allt längre upp i åldrarna, pensionärernas ökade köpkraft och de allmänna inkomstförändringarna i samhället. ${ }^{26}$ Detta har ökat sjukvårdskostnaderna och därmed lett till ett ökat behov av personal. Vidare har det generellt skett en medicinsk-teknisk utveckling som i många fall höjt kvaliteten inom vården, men som samtidigt inneburit stigande kostnader. Otvetydigt har det dessutom inom sjukvården funnits en självgenererande kostnadsspiral, som genom ny produktutveckling och ny teknik skapat nya behov med resultatet att efterfrågan på sjukvårdens tjänster ökat kraftigt. ${ }^{27}$ Man kan med fog påstå att

25 Det är möjligt att denna trend brutits de senaste åren.

26 Rolf Ohlsson, Sjukvårdskostnader och demografisk struktur. IHE, Lund, 1990.

27 Rolf Ohlsson, Per Broomé, Tore Nilstun, Operation sjukvård. SNS, 1983. en viktig underliggande orsak till sjukvårdens kraftiga expansion under 1900-talet har varit att utbudet skapat sin egen efterfrågan. ${ }^{28}$

Följande siffror belyser den enorma expansion som ägt rum. År 1910 fanns 10000 vårdplatser och under året vårdades 92000 patienter på sjukhusen under sammanlagt 3 miljoner vårddagar. År 1986 hade antalet vårdplatser ökat till 100 000, antalet intagna patienter till 1600000 och det sammanlagda antalet vårddagar till 33 miljoner. Samtidigt som befolkningen under perioden 1910-1986 ökade med ungefär 50 procent, var alltså i slutet av perioden antalet vårddagar 10 gånger fler än i periodens början. Till detta ska läggas kvalitetsaspekten som inneburit att kostnaden för en vårddag stigit betydligt mer än konsumentprisindex under perioden $\mathrm{i}$ fråga. Troligen har det reala priset per vårddag i det närmaste fördubblats. Allt talar dessutom för att antalet läkarbesök per 1000 invånare inom den öppna sjukvården ökade betydligt mer än antalet vårddagar per 1000 invånare inom den slutna vården.

Den svenska sjukvården tog ungefär $\mathrm{i}$ anspråk en procent av bruttonationalprodukten (BNP) vid sekelskiftet, och sysselsatte en försumbar del av arbetsstyrkan; enligt folkräkningen 191018000 personer, varav 70 procent kvinnor. År 1985 hade sjukvårdens andel av BNP stigit till 9 procent. Sektorn sysselsatte detta år 11 procent av den totala arbetsstyrkan eller i absoluta tal 450000 , varav över 80 procent var kvinnor.

28 Denna princip går vanligtvis under benämningen Say's lag. 


\section{Barnomsorgen}

Ett tredje viktigt inslag har varit att samhället och kommunen utvidgat sin verksamhet i fråga om barnomsorg. Denna utökade verksamhet kan först och främst sägas vara en effekt av att de gifta kvinnorna gett sig ut på arbetsmarknaden. Funktioner som tidigare utfördes i hemmet, som exempelvis vård av barn, har i och med denna förändring på arbetsmarknaden alltmer förts över i samhällets och kommunens regi. Det ska dock påpekas att det redan under 1900-talets första decennier fanns barnkrubbor som under arbetstid tog hand om barn till fattiga, förvärvsarbetande mödrar. Barnkrubborna drevs då emellertid av välgörenhetsföreningar.

Ideologiska motiv har också spelat en stor roll i sammanhanget och har varit viktiga för att förklara barnomsorgens expansion. Man kan här följa två helt olika utvecklingslinjer där båda var och en för sig haft sin grund i realekonomiska och demografiska förändringar.

Som vi tidigare visat gifte sig kvinnorna sent i seklets början. Många, uppskattningsvis 30 procent, förblev ogifta livet igenom. Från samhällets sida fanns därför behov av att finna meningsfulla arbetsuppgifter för dessa kvinnor. Ett uttryck för detta, och som kan sägas avspegla den tidsanda som rådde och de värderingar som fanns $i$ början av seklet, var den s.k. Fröbelideologin. Denna innebar att de ogifta kvinnorna skulle stödja familjerna genom att utbilda sig för barnuppfostran m.m. De ogifta kvinnorna skulle helt enkelt bli "andliga mödrar«. De barnträdgårdar som påbörjade sin verksamhet i början av seklet var konkreta uttryck för denna ideologi. ${ }^{29}$
Den Fröbelska ideologin och pedagogiken blev emellertid omsprungen av verkligheten genom att giftermålsfrekvenserna började öka kraftigt och antalet äldre ogifta kvinnor därigenom blev allt färre. Den ersattes på 1930- och 40-talen av en ny ideologi med helt nya sätt att se på barn, på kvinnors arbete och på barnomsorg. Denna nya ideologi brukar förknippas med Alva Myrdal och hennes bok Stadsbarn (1935). Hon anklagar i boken Fröbeltraditionen och -pedagogiken för att syssla med "småpyssel" och vill istället ersätta den med vad som kan benämnas "socialpedagogiku. Den nya ideologin, i kombination med de demografiska och realekonomiska förändringarna, fick som resultat att barnomsorgen övergick i offentlig regi och fick ett helt annat innehåll än tidigare. Dessutom innebar den nya ideologin att barnomsorgen skulle byggas ut.

Denna socialisering av familjen, med en kraftigt utbyggd offentlig barnomsorg, skedde parallellt med att de gifta kvinnornas förvärvsintensiteter ökade markant. Så småningom började också tendenser till den traditionella borgerliga kärnfamiljens upplösning märkas (samboende utan formellt giftermål, ökade skilsmässor, annorlunda arbetsfördelning i hemmen m.m). Även detta innebar en ökad efterfrågan på offentlig barnomsorg.

Vid mitten av 1980-talet fanns över 40 procent av alla barn i åldrarna 0-6 i daghem eller familjedaghem (deltidsgrupper ej medräknade) och 17 procent av barnen i åldrarna 7-12 år i fritidshem och familje-

29 Ingegärd Tallberg Broman, När arbetet var lönen. Malmö, 1991. 
daghem. År 1985 var över 150000 personer, varav 91 procent kvinnor, sysselsatta med barnavård och ungdomsvård i offentlig regi.

\section{Individ- och familjeomsorgen}

När det gäller individ- och familjeomsorgen är det främst "fattigvårdens" och socialhjälpstagandets utveckling som har varit dominerande, och som därför är av intresse i sammanhanget. Tyvärr finns det få undersökningar i Sverige som försökt belysa och analysera de bakomliggande ekonomiska och sociala orsakerna till socialhjälpstagandets utveckling i Sverige i ett långtidsperspektiv. ${ }^{30}$

Några reflektioner kan dock göras på basis av det statistiska material som finns tillgängligt. I början av 1900-talet fanns det ett stort antal personer som på ett eller annat sätt var tvingade att utnyttja fattigvården, genomsnittligt under seklets första decennium 4 procent av totalbefolkningen. Antalet ständiga och tillfälliga understödstagare kulminerade år 1917 med 258000 personer eller 4,5 procent av befolkningen. Denna andel kan tyckas förvånansvärt hög, men det bör då betänkas att fattigvården vid denna tidpunkt ofta var den enda tillflykten för gamla, långvarigt sjuka, handikappade och arbetslösa. Vanligtvis räckte inte arbetslöshetsunderstödet till för familjens uppehälle, och den statliga folkpensionen, införd 1913, gick knappast heller att leva på. En jämförelse med hur många som på 1980-talet tvingades att an-

30 Ett undantag utgör Karsten Lundequist, Socialhjälpstagande. Utveckling och orsaker 19451965. Uppsala, 1976. lita individ- och familjeomsorgen blir därför inte särskilt rättvis.

Om vi från 1917 års uppgifter räknar bort gamla, sjuka, handikappade och arbetslösa, blir resultatet att socialhjälpstagarna endast utgjorde ett par procent av befolkningen, mestadels barn. Detta ska då jämföras med 1989 års uppgifter. ${ }^{31}$ Detta år erhöll mer än 500000 personer socialbidrag, varav hushåll med hushållsföreståndare över 65 år var så få att de helt kan bortses ifrån. Ungefär 6 procent av befolkningen erhöll socialbidrag år 1989.

Att vara fattig i seklets början var något helt annat än att vara fattig under 1980-talet. Denna sats är i det närmaste truistisk men blir meningsfull om vi lägger in ordet relativt före fattig. Då får vi i ett nötskal den viktigaste orsaken till att socialhjälpstagarna i de produktiva åldrarna, inklusive barnen, ökat sedan sekelskiftet i den omfattning som de gjort. Vad som ansågs vara fattigt i början av seklet låg långt under genomsnittsstandarden för folk i allmänhet, enligt de då rådande normerna och värderingarna. Vad som ansågs vara fattigt år 1989 låg däremot förhållandevis nära genomsnittsstandarden.

Den kraftigt ökade hjälpbenägenheten måste alltså främst sökas i att inställningen till vad som ska betraktas som en socialt nödvändig levnadsstandard har förändrats över tiden; inte bara i absoluta utan främst i relativa termer. Drivkrafterna bakom denna förändrade inställning till wfattigdom» står i sin tur att finna i den allmänna

31 Jag har valt 1989, därför att ekonomiskt bistånd till asylsökande ej ingår i socialbidragen fro.m detta år. 
standarförbättringen, i inkomstutvecklingen, i de ideologiska värdeförskjutningarna samt sannolikt främst i den kraftiga inkomstutjämning som generellt ägt rum i samhället. Socialbidragsnormen har i princip varit knuten till levnadsnivån för en låginkomsttagare. Eftersom låginkomsttagaren närmat sig medelinkomsttagaren har därigenom också socialbidragsnormen höjts markant. Som grundläggande hypotes till den ökade hjälpbenägenheten och variationerna över tiden kan då framföras att de varit nära relaterade till inkomstskillnaderna i samhället. När dessa varit små har hjälpbenägeneheten varit hög, och vice versa.

\section{Utbildningssektorn}

Det femte viktiga inslaget bakom omsorgssamhällets framväxt har bestått i en kraftig expansion inom skolväsendet, såväl inom den obligatoriska som inom den ickeobligatoriska skolan. En mångfald av motiv har här legat bakom kapacitetsutbyggnaden. Utbildning har setts som ett viktigt medel att skapa ökad jämlikhet i samhället. Den omfattande strukturomvandlingen inom näringslivet har inneburit att många av de kunskaper och färdigheter som krävs för en effektiv produktion både på varuoch tjänstesidan har förändrats radikalt över tiden. Konsekvensen av denna omvandling har blivit att näringslivet efterfrågat en helt annan typ av arbetskraft med en annan utbildning, än vad man gjorde i det traditionella industrisamhället. Ytterligare en nödvändig förutsättning för att en expansion inom utbildningsväsendet ägt rum har varit att individerna i samhället velat utbilda sig. De stigande inkomsterna och de förändrade relativlönerna har varit några viktiga faktorer bakom denna ökade individuella efterfrågan på utbildning.

I detta sammanhang har de demografiska förändringarna spelat en stor roll. Även här kan man anföra en hypotes från »new home economicsu-teorin. Så har familjerna övergått från att ha en kvantitetssyn på barn till att ha en kvalitetssyn, där utbildning utgjort ett viktigt element för att höja kvaliteten på barnen. Särskilt har de stora barnkullarna från 40 -talet varit viktiga $\mathrm{i}$ detta sammanhang. Många av de reformer som genomförts på olika nivåer under efterkrigstiden kan ses som försök att lösa de speciella problem som varit förknippade med den obalans i åldersstrukturen som krigsårens födelsemönster gav upphov. Det har också visats, i varje fall för perioden 1920-1977, att storleken på den ålderskohort som en individ tillhör i hög grad har påverkat dennes efterfrågan på utbildning. I en stor åldersgrupp har relativt sett många efterfrågat högre utbildning. I en liten åldersgrupp har relativt sett få efterfrågat högre utbildning. ${ }^{32}$

Utbildningsexpansionen belyses av följande: i början av seklet var den obligatoriska skoltiden sex år. Av folkskoleeleverna gick genomsnittligt ungefär 10 procent vidare till den icke-obligatoriska skolan, dvs till realskolan eller till andra skolor på denna nivå (tekniska skolor m.m). Av dessa gick i sin tur ungefär 30 procent vidare till gymnasiet..$^{33}$ Ungefär 90 procent av barnen och ungdomarna gick alltså ut på arbets-

32 Rolf Ohlsson, Högre utbildning och demogra-

fisk förändring, Lund, 1986

33 Enligt egna bearbetningar av skolstatistiken. 
marknaden i 12-13 årsåldern, 7 procent i 16-17 årsåldern samt 3 procent när de var över 20 år.

Fram till 1980-talet hade den obligatoriska skoltiden förlängts till nio år, men efter avslutad grundskola gick närmare 90 procent vidare till gymnasiets olika linjer. Av dessa gick sedan minst 50 procent vidare till högskolestudier i någon form. 10 procent gick alltså ut på arbetsmarknaden i 16-17 års åldern, medan 90 procent var äldre än 18 år vid inträdet på arbetsmarknaden. Genomsnittligt skedde ungdomarnas inträde på arbetsmarknaden under 1980-talet närmare tio år senare än vad som var fallet i början av seklet.

Det ska i sammanhanget påpekas att denna utbildningsexpansion i mångt och mycket har varit en flickornas utbildningsexpansion, särskilt efter 1927 års skolreform. Detta är en aspekt som inte får glömmas om man vill hävda att näringslivet har utvecklats från att ha varit helt mansdominerat till att i större utsträckning domineras av kvinnor.

Dessutom ska det betonas att utbildningsexpansionen skett gradvis under hela 1900-talet genom att den obligatoriska skoltiden förlängts. Om vi istället bestämmer storleken på utbildningsexpansionen genom att mäta antalet ungdomar som gått vidare i den icke-obligatoriska skolan, har den accelererat över tiden. Man kan här särskilt peka ut 1960-talet som utbildningsoptimismens decennium. Utbildning betraktades då som ett av de främsta jämlikhetsinstrumenten som stod till samhällets förfogande. Samtidigt sågs utbildning som ett av de viktigaste verktygen för att öka produktiviteten i näringslivet och för att i största allmänhet befrämja den ekonomiska tillväxten. De stora ålderskohorterna från 40-talet spelade också en stor roll i sammanhanget.

År 1910 var 27000 personer, varav 65 procent kvinnor, sysselsatta inom utbildningssektorn. År 1985 hade detta antal ökat till 270000 personer, alltså 10 gånger så många. Andelen kvinnor var ungefär densamma som 1910, dvs. 65 procent.

Dessa fem genomgripande förändringar i den sociala och ekonomiska strukturen, där de demografiska faktorerna både direkt och indirekt spelat en avgörande roll, har tvingat fram kollektiva lösningar och en kollektiv finansiering för att tillfredsställa de gradvis växande behoven. De ökade behoven och finansieringen, som tagit sig uttryck i ett kraftigt ökat skatteuttag, har varit den ena sidan av myntet. Men om vi vänder på myntet, har det, när det gäller personalsidan, inneburit omfattande konsekvenser.

Av tradition, genom gamla tiders sätt att tänka, och troligen beroende på ett stort inslag av fördomar, har kvinnor ansetts vara särskilt lämpade för omvårdnads- och omsorgsarbete. Den ökade efterfrågan på personal inom omsorgsyrkena har därför främst riktats mot den arbetskraftsreserv som funnits i form av kvinnor, speciellt de gifta och samboende. De alternativ som stått till buds har dessutom inte varit särskilt attraktiva och ibland närmast omöjliga. Att rationalisera verksamheten inom de vårdande sektorerna har generellt tett sig problematiskt, bland annat genom det sätt som produktionen av dessa tjänster varit organiserat på. Så har det inte existerat några priser som avspeglat de reella kostnaderna, ef-

Ohlsson - Det svenska välfärdssamhällets framväxt - tacka kvinnorna för det 
tersom verksamheten nästan uteslutande finansierats genom skatter. Därigenom har det inte heller funnits några incitament att få fram ny teknik eller att genomföra omfattande organisationsförändringar för att öka produktiviteten. Den ökade efterfrågan och det ökade resursbehovet har därför i princip manifesterat sig i ett lika stort personalbehov, där det under perioder av personalbrist uppstått »köer«. Att använda alternativ arbetskraft har vidare i många fall tett sig omöjligt. Det har till exempel endast varit möjligt att använda invandrare i begränsad omfattning inom den offentliga sektorn på grund av språksvårigheter och kulturella skäl m.m.

Följande siffror belyser utvecklingen på personalsidan och talar sitt eget tydliga språk: av de ungefär 1 miljon yrkesverksamma år 1910, exklusive jordbruk och hemarbete, arbetade 50000 med sjukvård, fattigvård, socialt arbete och undervisning. 1985 arbetade ungefär 1 miljon personer inom samma verksamheter, där en stor majoritet utgjordes av kvinnor.

\section{Avslutande reflektion}

Det svenska välfärdssamhällets utveckling har ingått i ett komplicerat förlopp, där det inte går att urskilja några enkla orsak-ver- kan samband. Jag har i denna artikel velat betona interaktionen mellan tre långsiktiga processer. För det första de demografiska faktorerna, som varit verksamma på flera olika plan. Beroende på allt färre barn, en förändrad familjestruktur, en minskad dödlighet och en radikalt förändrad åldersstruktur har för det andra efterfrågan på offentligt producerade tjänster ökat kraftigt: äldreomsorg och hälso- och sjukvård. Men även indirekt har de demografiska faktorerna påverkat andra sektorer av den offentliga sektorn: barnomsorg, individ- och familjeomsorg samt utbildning. För det tredje har den offentliga sektorns expansion inneburit att kvinnorna alltmer gett sig in på den öppna arbetsmarknaden. Andra strukturella och konjunkturella förändringar i ekonomin har i detta sammanhang varit viktiga, vilket i kombination med den offentliga sektorns ökade behov på personal resulterat $\mathrm{i}$ en kraftig relativ löneökning för kvinnor jämfört med män över tiden. Detta har i sin tur påverkat den demografiska strukturen. Enligt min mening är det först när man beaktar denna långsiktiga interaktion mellan demografisk struktur, arbetsmarknad och offentlig sektor som det svenska välfärdssamhällets framväxt under 1900-talet blir möjlig att förstå. 


\section{Summary}

\section{The growth of the Swedish welfare society - be grateful to the women}

The growth of the Swedish welfare society has often been discussed in an institutional and political perspective. In this article I argue that an analysis of the growth of the welfare society must take into account long-term changes, which have interacted in a complex way. Demographic changes have been important both directly and indirectly. Fewer children, lower mortality and changes in the family structure have resulted in a growing demand for publically produced services (care of the elderly, health care, child care, social assistance and education). The growing pub- lic sector, together with structural and short-term changes in the economy have meant a growing demand for female labour and increasing relative wages for women compared with men. This in turn has affected the demographic changes.

In the article I have tried to identify the long-term changes by comparing the situation at the beginning of the century with the situation in the 1980s. Furthermore, I use in a tentative way "new home economics" explanations for the long-term changes. 